\title{
Dominant Occurrence of Rhipicephalus Sanguineus on Dogs From Two Western Counties of Romania (Arad and Timiș)
}

\author{
Mirela IMRE ${ }^{1 *}$, Marius S. ILIE ${ }^{1}$, Kàlmàn IMRE ${ }^{2}$, and Gheorghe DĂRĂBUȘ ${ }^{1}$ \\ ${ }^{1}$ Department of Parasitology and Parasitic Diseases, Banat University of Agricultural Sciences and Vet- \\ erinary Medicine "King Michael I of Romania" of Timișoara, Romania \\ ${ }^{2}$ Department of Animal Production and Veterinary Public Health, Banat University of Agricultural Sci- \\ ences and Veterinary Medicine "King Michael I of Romania" of Timișoara, 300645, Romania, \\ * Corresponding author e-mail: mirela.imre@gmail.com
}

Bulletin UASVM Veterinary Medicine 71(2) / 2014,

Print ISSN 1843-5270; Electronic ISSN 1843-5378

DOI:10.15835/buasvmcn-vm: 10394

\begin{abstract}
The study was undertaken to provide data on the occurrence of ticks parasitizing dogs in two western counties of Romania, namely Arad and Timiș. A total of 869 specimens have been collected from 140 randomly selected dogs in a four year longitudinal period (2010-2014) and have been identified at species level. Overall, $45.1 \%$ were identified as Rhipicephalus sanguineus sensu lato (s.l.), and $27.3 \%, 25.9 \%, 1,5 \%$ and $0.2 \%$ as Ixodes ricinus, Dermacentor reticulatus, Dermacentor marginatus and Haemaphysalis punctata, respectively. Regarding the dogs, $55.0 \%$ were infested with $R$. sanguineus sensu lato, $25.0 \%$ with $I$. ricinus, $14.3 \%$ with $D$. reticulatus, $4.3 \%$ with $D$. marginatus and $1.4 \%$ with $H$. punctata. The present survey highlighted the dominance of $R$. sanguineus sensu lato on dogs in the screened region, which may pose a risk in serving as reservoirs and disseminating important tick-borne pathogens like Babesia canis, Ehrlichia canis, Rickettsia conorii or Hepatozoon canis.
\end{abstract}

Keywords: dog, R. sanguineus, ticks

Introduction: Members of suborder Ixodida (phylum Arthropoda), usually known as hard ticks, are considered one of the most important group of vectors for many pathogens including bacteria, helminths, protozoa and viruses (Dantas-Torres, 2010). Over the last few years, the continuous expansion of ticks and tick - borne diseases has received much attention throughout European countries including Romania. Therefore, the continuous follow-up of the distribution of tick species in each European Union member state, and in other parts of the world in general, together with the evaluation of the risk that is poses are crucial, especially on pets which live in close relation to humans.

Aims: The survey aimed to investigate the occurrence of tick species on dogs living in two western counties of Romania (Arad and Timiș), in order to offer importantinformation to smallanimal practitioners and veterinary health authorities.
Materials and Methods: From 2010 to 2014, a total of 869 tick specimens were removed from 140 randomly selected dogs presented for medical examination at the Veterinary Clinics of the Faculty of Veterinary Medicine, Timissoara or in private veterinary practices located in Arad and Timiș counties. Sampling was made in different months of year enrolling a variable number of dogs as presented in Table 1 in the results section. As a first step, the collected ticks were placed into plastic containers and preserved in $70 \%$ ethanol until further identification at species level. Identification of tick species was done according to Estrada-Peña et al. (2004).

Results: The distribution of the tick species according to the sampling years, months and examined dogs are summarized in Table 1. During an approximately four year screening period, from a total of 869 collected ticks, 392 (45.1\%) were identified as $R$. sanguineus sensu lato, 237 
Table 1. Occurrence of tick species on dogs according to the sampling years, months and examined dogs in two western counties of Romania (Arad and Timiș)

\begin{tabular}{|c|c|c|c|c|c|}
\hline $\begin{array}{ll}\begin{array}{l}\text { Tick } \\
\text { species }\end{array} & \text { Year } \\
\end{array}$ & 2010 & 2011 & 2012 & 2013 & 2014 \\
\hline & \multicolumn{5}{|c|}{ No. month of year/no. of collected tick/no. of enrolled dogs } \\
\hline $\begin{array}{l}\text { R. sanguineus } \\
\text { sensu lato }\end{array}$ & IV $/ 9 / 5$ & $\begin{array}{c}\text { III/21/8; } \\
\text { IV/2/2;V/22/6; } \\
\text { VIII/7/2; X/2/1 }\end{array}$ & $\begin{array}{c}\mathrm{III} / 26 / 6 ; \\
\mathrm{IV} / 27 / 5 ; \\
\mathrm{V} / 34 / 2 ; \mathrm{VI} / 4 / 1 \\
\mathrm{VII} / 7 / 2\end{array}$ & $\begin{array}{l}\text { III/29/3; IV/5/1; } \\
\text { V/50/11; VI/18/3; } \\
\text { VII/10/1; X/20/3 }\end{array}$ & $\begin{array}{c}\mathrm{III} / 25 / 1 ; \\
\mathrm{IV} / 3 / 1 ; \\
\mathrm{V} / 66 / 12 ; \\
\mathrm{VI} / 5 / 1\end{array}$ \\
\hline I. ricinus & $\begin{array}{c}\mathrm{IV} / 5 / 2 ; \mathrm{V} / 8 / 1 ; \\
\mathrm{VII} / 13 / 2\end{array}$ & $\begin{array}{c}\text { III/19/5; IV/4/1; } \\
\text { V/11/3 }\end{array}$ & $\begin{array}{c}\mathrm{III} / 20 / 2 ; \\
\mathrm{IV} / 8 / 2 ; \mathrm{V} / 9 / 2\end{array}$ & $\begin{array}{c}\text { III/5/1; IV/4/1; } \\
\text { V/46/6; X/5/1 }\end{array}$ & $\begin{array}{l}\mathrm{V} / 63 / 4 ; \\
\mathrm{VI} / 17 / 2 \\
\end{array}$ \\
\hline D. reticulatus & $\mathrm{IV} / 9 / 2 ; \mathrm{V} / 6 / 1$ & $\mathrm{~V} / 7 / 2$ & $\begin{array}{c}\mathrm{III} / 56 / 3 ; \\
\mathrm{V} / 2 / 1 ; \mathrm{XI} / 20 / 1\end{array}$ & $\mathrm{~V} / 92 / 6$ & $\begin{array}{l}\mathrm{V} / 27 / 3 \\
\mathrm{VI} / 6 / 1\end{array}$ \\
\hline D. marginatus & - & - & III $/ 4 / 2$ & $\mathrm{IV} / 5 / 2$ & $\begin{array}{l}\mathrm{V} / 2 / 1 \\
\mathrm{VI} / 2 / 1\end{array}$ \\
\hline H. punctata & & $\mathrm{V} / 1 / 1$ & $\mathrm{~V} / 1 / 1$ & & \\
\hline $\begin{array}{c}\text { Total collected } \\
\text { ticks }\end{array}$ & 50 & 96 & 216 & 289 & 218 \\
\hline
\end{tabular}

$(27.3 \%)$ as I. ricinus, $225(25.9 \%)$ as D. reticulatus, $13(1.5 \%)$ as $D$. marginatus and $2(0.2 \%)$ as $H$. punctata, respectively. Concerning the enrolled dogs, 77 (55.0\%) were infested with $R$. sanguineus sensu lato, $35(25.0 \%)$ with I. ricinus, $20(14.3 \%)$ with $D$. reticulatus, $6(4.3 \%)$ with $D$. marginatus and $2(1.4 \%)$ with $H$. punctata, respectively.

Except the first sampling year, $R$. sanguineus sensu lato has been recorded most frequently on the examined dogs. The occurrence of $I$. ricinus and $D$. reticulatus was a common finding. The reason why $D$. marginatus has not been found in the years 2010 and 2011, and why H. punctata has been present only in the years 2011 and 2012, respectively, remain open questions. In agreement with the current knowledge regarding the $R$. sanguineus sensu lato distribution in the screened counties (Chițimia, 2010), the brown dog tick can be considered the main tick species parasitizing dogs. However, caution should be taken in interpreting of the results because the sample collection was done randomly, including a variable number of dogs examined predominantly in spring and summer months.

Interestingly, until now, except the imported cases, in the neighboring Hungary the presence of $R$. sanguineus sensu lato has not been recorded, even if the Hepatozoon canis pathogen transmitted by the brown dog tick has been recently reported (Hornok et al., 2013).

Further studies enrolling a large number of ticks and dogs are still needed to a better under- standing of the distribution of ticks in dogs in western Romania.

Conclusions: Based on the findings of the current study, in Arad and Timiss counties $R$. sanguineus sensu lato can be considered the main tick parasitizing dogs. The results of the current survey provide useful insight for small animal practitioners in the screened counties, regarding the risk that is posed in the transmission of important tick - borne pathogens like Babesia canis, Ehrlichia canis, Rickettsia conorii or Hepatozoon canis.

Acknowledgements. This paper was published under the frame of European Social Fund, Human Resources Development Operational Programme 2007-2013, projectno. POSDRU/159/1.5/S/132765.

\section{References}

1. Chiţimia L (2007). Căpuşe Ixodide. Ed. Mirton, Timişoara

2. Dantas-Torres F, (2010). Biology and ecology of the brown dog tick, Rhipicephalus sanguineus. Parasites \& Vectors. $3: 26$.

3. Estrada-Peña A, Bouattour A, Camicas JL, Walker AR (2004). Ticks of domestic animals in the Mediterranean region. A guide to identification of species. Ed. Univ. Zaragoza, Spain.

4. Hornok S, Tánczos B, Fernández de Mera IG, de la Fuente J, Hofmann-Lehmann R, Farkas R (2013). High prevalence of Hepatozoon-infection among shepherd dogs in a region considered to be free of Rhipicephalus sanguineus. Vet Parasitol. 196:189-93. 